\title{
HUBUNGAN KARAKTERISTIK INDIVIDU TERHADAP KETAHANAN ACUTE STRESS DISORDER (ASD) PASKA BENCANA LONGSOR
}

\author{
Norman Wijaya Gati ${ }^{1}$, Nazaruddin Latif ${ }^{2}$ \\ STIKES ‘Aisyiyah Surakarta \\ J1 Kapulogo no.3 Griyan Pajang Laweyan Surakarta \\ E-mail :norman_gati@ymail.com
}

\begin{abstract}
Abstrak
Latar Belakang: Bencana adalah kejadian yang tidak bisa diprediksi dan terjadi secara mendadak. Bencana berdampak pada fisik, dan psikologis. Dampak psikologis yang muncul pada saat kejadian bencana salah satunya ASD. Individu mengembangkan respon yang berbeda-beda pada saat terjadi bencana.Tujuan Penelitian: penelitian ini bertujuan untuk mengetahui hubungan karakteristik individu terhadap ketahanan ASD paska bencana longsor. Hasil: menunjukan bahwa karakteristik responden, umur dan penghasilan memiliki korelasi denganASD ( $p$-value $<0.05)$. Sedangkan jenis kelamin dan pendidikan tidak memiliki korelasi terhadap kejadian ASD. Simpulan dan Saran: Berdasarkan hasil analisis didapatkan bahwa ketahanan seseorang terhadap kejadian ASD dipengaruhi oleh faktor karakteristik individu yang meliputi umur dan penghasilan. Sedangkan karakteristik individu yang meliputi jenis kelamin dan pendidikan tidak memiliki korelasi terhadap ketahanan. Sebagai saran, puskesmas yang mempunyai daerah binaan rawan bencana sebaiknya mengadakan screening ASD pada penduduk guna mengantisipasi terjadinya ASD paska bencana. Meningkatkan kemampuan individu untuk siap menghadapi kejadian traumatik.
\end{abstract}

Kata Kunci: Ansietas, Gangguan stres akut, Karakteristik individu 


\title{
INDIVIDUAL CHARACTERISTIC RELATIONS TOWARD ACUTE STRESS DISORDER (ASD) RESILIENCE POST LANDSLIDE DISASTER
}

\author{
Norman Wijaya Gati ${ }^{1}$, Nazaruddin Latif ${ }^{2}$ \\ STIKES ‘Aisyiyah Surakarta
}

Jl Kapulogo no.3 Griyan Pajang Laweyan Surakarta

E-mail :norman_gati@ymail.com

\begin{abstract}
Background: Disasters are unpredictable events and occur suddenly. Disasters have physical, and psychological impact. The psychological impact that emerged during the disaster event was ASD. Individuals develop different responses in the event of a disaster. Research Objectives: This research was analyzed to determine the relationship of individual characteristics toward ASD resilience after landslide disaster. Result: This research show that characteristic of respondent, age and income have correlation with ASD ( $\mathrm{p}$-value $<0.05)$. While sex and education have no correlation to ASD events. Conclusions and Suggestions: Based on the analysis results obtained that the resistance of a person to the incidence of ASD was influenced by individual characteristic factors, include age and income. While individual characteristics gender and education have no correlation to ASD resilience. Suggestion: Primary health care should have screening program to ASD's sign and symptom on the population to anticipate the occurrence of post-disaster ASD. Increase the ability of individuals to be ready to deal with traumatic events.
\end{abstract}

Keywords: Anxiety, Acute Stress Disorder, Individual characteristic 


\section{PENDAhuluan}

Bencana merupakan kejadian yang tidak dapat diprediksi oleh manusia. Bencana dibedakan menjadi dua berdasarkan kelompok penyebabnya yaitu bencana alam dan bencana non alam. Kedua jenis bencana diatas, beresiko untuk menimbulkan kerugian baik pada manusia maupun pada sarana dan prasaran yang ada. Kondisi paska bencana menimpulkan kondisi krisis kesehatan dan membutuhkan bantuan dari wilayah lain untuk menghadapi kondisi krisis tersebut (UU No 24 Tentang Penanggulangan Bencana, 2007; Allen \& John, 2005; Oklahoma

State Departement of Health, 2012; Pusat Penanggulangan Krisis Kesehatan Kementrian Kesehatan RI, 2015).

Kejadian bencana dapat terjadi pada seluruh negara di penjuru dunia. Benua dengan angka bencana tertinggi adalah benua asia yaitu sebesar 38,1\% sedangkan benua dengan angka terendah untuk kejadian bencana adalah Oceania 4,2\% (Oklahoma State Departement of Health, 2012). Adapun jenis bencana yang menjadi trending pada tahun 2003-2012 adalah banjir dengan jumlah kejadian 172. Terjadi penurunan pada tahun 2013 menjadi 145 kejadian (International Disaster Databased, 2014). Kejadian bencana di Negara asia cenderung jenis bencana meteorological dengan badai tropis sebanyak 1068 kejadian. Indonesia sebagai salah satu Negara asia yang terletak di ujung pergerakan tiga lempeng dunia yaitu Eurasia, IndoAustralia dan Pasifik membuat Negara Indonesia menjadi salah satu Negara dengan angka kejadian bencana alam yang tinggi. Lokasi ini memungkinkan Indonesia untuk rentan mengalami pergerakan tanah. Angka kejadian tanah longsor sebanyak $14,5 \%$ pada tahun 2012-2013 dan kejadian ini meningkat menjadi $29,3 \%$ pada tahun 2014-2015. Banjarnegara merupakan wilayah jawa tengah dengan kondisi dengan angka kejadian longsor yang terus meningkat setiap tahunya, tercatat terjadi peningkatan menjadi 379 kejadian (BNPB, 2015).

Akibat dari kejadian bencana dapat menyebabkan kerugian.Kerugian dari segi fisik meliputi kehilangan nyawa, luka-luka, kehilangan harta benda, fasilitas umum, ekonomi. Kerugian dari segi psikososial meliputi adanya 
perasaan kehilangan, kecemasan, stress (Center For Disaster Philanthropy, 2014; Pusat Penanggulangan Krisis Kesehatan Kementrian Kesehatan RI, 2015).Respon psikososial yang dapat muncul berupa perubahan emosi, pikiran dan perilaku, sehingga membutuhkan support koping yang memadai (Allen, 2005; Langan \& James, 2005). Respon individu terhadap jenis stressor bencana berbeda-beda tergantung pada pengalaman sebelumnya, banyaknya stressor, dan dukungan social (Stuart, 2013).

Hasil studi pendahuluan dari responden yang mengalami paska bencana longsor dusun Sampang di kabupaten banjarnegara. Sejumlah 27 korban bencana alam mengalami tingkat resiliensi yang baik, yaitu sejumlah 25 responden mengalami perubahan angka Acute stress disorder (ASD) setelah dilakukan tindakan cognitive behavior therapy (CBT). Berdasarkan latar belakang diatas, peneliti ingin menganalisis karakteristik individu terhadap ketahanan ASD paska bencana longsor.

\section{METODE PENELITIAN}

Hubungan Karakteristik Individu ......
Penelitian ini menggunakan metode kuantitatif desain crossectional. Pengambilan sampel dilakukan dengan total sampling menggunakan screening ASDS dan kriteria inklusi. Sejumlah 27 karakteristik responden dilakukan analisis. Kriteria inklusi meliputi : Berada pada rentang usia 20-60 tahun (dewasa), Nilai Acute Stress Disorder Scale $($ ASDS $)<56$, Tidak sedang dalam pengobatan dan atau sakit kritis, Tinggal di wilayah Desa Sampang dan Bersedia mengikuti penelitian sebagai responden. Analisis statistik yang digunakan yaitu analisis bivariat komparasi koefisien kontingensi dan korelasi spearman.

\section{HASIL DAN PEMBAHASAN}

Karakteristik individu meliputi umur, jenis kelamin, penghasilan.

a. Umur

Rata-rata umur pada responden adalah 38 tahun. Umur 38tahun merupakan tahapan usia dewasa dengan tugas perkembangan mempunyai tanggung jawab besar, menyiapkan generasai setelahnya, mempertahankan keharmonisan dengan pasangan, berfikir realistis, berorientasi pada tugas dan tujuan hidup (Perry \& Potter, 
2009). Hasil analisis bivariat didapatkan hasil $p$ value 0.026 dengan $\mathrm{r}$ -0.427 , hal ini berarti bahwa semakin tinggi umur maka resiko untuk mengalami ASD semakin rendah. Umur memiliki pengaruh yang negative terhadap kejadian ASD Diehl, Coyle \& Vief (1996) menjelaskan bahwa semakin usiaindividu bertambah makan akan terpapar dengan bermacammacam stressor. Semakin banyak stressor yang dialami oleh individu akan membuat individu semakin banyak pembelajaran dan membentuk koping yang adaptif. Hal ini yang membuat resiliensi terhadap ASD tinggi.

b. Jenis kelamin

Jenis kelamin pada responden sebanyak $55,6 \%$ berjenis kelamin laki laki dan sisanya $44.4 \%$ berjenis kelamin perempuan. Hasil analisis bivariate menunjukan nilai $p$ value 0.869 . Hal ini menunjukan bahwa jenis kelamin tidak mempengaruhi kejadian ASD pada korban paska bencana longsor. Data diatas ditemukan bahwa lebih tinggi kejadian laki-laki dengan kejadian ASD daripada perempuan, dengan selisih $0,02 \%$. Perempuan pada dasarnya memiliki resiko yang tinggi mengalami Hubungan Karakteristik Individu . . . . . . stres saat terjadi bencana (WHO, 2010).Meskipun demikian jenis kelamin perempuan memiliki kemampuan prosesing ego yang terintegrasi dan koping strategi kognitif yang fleksibel. Kondisi tersebut membuat wanita memiliki problem solving yang kreatif dengan melibatkan emosional dan kognitif (Diehl, Coyle \& Vief, 1996). Peran gender di wilayah penelitian memiliki peran yang sama besar anatar perempuan dan laki-laki, sehingga kedua jenis kelamin tersebut memiliki tugas dan tanggung jawab serta beban yang sama. Kondisi ini yang membuat bahwa kedua jenis kelamin tidak memilihhi hubungan terhadap kejadian ASD paska bencana longsor.

c. Pendidikan

Sebagian besar responden memiliki pendidikan SD sejumlah 20 responden. Analisis karakteristik pendidikan tidak memiliki hubungan terhadap kejadian ASD. Tingkat pendidikan yang tinggi akan mempengaruhi kemampuan kognitif, sehingga mampu mengambil keputusan dengan baik. Semakin tinggi kemampuan kognitif maka akan semakin baik dalam berespon terhadap stressor (Strawbridge, 2002). Penelitian 
ini menunjukan bahwa tingkat pendidikan formal tidak mempengaruhi keadaan ASD. Responden memiliki nilai resiliensi yang tinggi terhadap ASD, meskipun sebaian besar berpendidikan SD. Notoatmojo, 2003 menyebutkan bahwa pendidikan merupakan cara untuk meningkatkan pengetauan dan membuat klien mengetahui cara berkoping yang baik. Pendidikan didapat tidak hanya pada jalur formal tetapi juga jalur informal. Pendidikan informal merupakan pembelajaran yang diperoleh individu sepanjang kehidupannya.

d. Penghasilan

Berdasarkan uji statistic didapatkan hasil korelasi dengan arah negative antara penghasilan dan kejadian ASD (0.456) dengan $p$ value 0.017. Semakin tinggi penghasilan maka angka kejadian ASD semakin rendah. Kondisi ini sesuai dengan pendapat dari Taylor, 2010: Ranimpi, 2009 yang menyebutkan bahwa ketahanan psikologis dari individu dipengaruhi oleh kondisi social ekonomi. Kondisi stress juga akan semakin meningkat dengan kondisi perekonomian individu yang tidak pasti (Cassel, et all, 2003). Sebagian besar responden memiliki Hubungan Karakteristik Individu ...... . penghasilan di bawah UMR, meskipun demikian angka resiliensi terhadap ASD tinggi, hal ini dikarenakan setelah kejadian bencana warga mendapatkan kompensasi materiil dan pelatihanpelatihan. Kondisi ini membuat warga memiliki mata pencaharian dan penghasilan yang lebih baik dari sebelum kejadian bencana.

\section{SIMPULAN DAN SARAN}

Individu mengembangkan respon yang berbeda-beda saat menghadai situasi yang mengancam kehidupannya. Bencana merupakan kejadian yang biasanya terjadi secara mendadak tanpa bisa diprediksi. Kejadian bencana menimbulkan dampak yang beragambagi individu, dampak yang terlihat meliputi dampak fisik, sedangkan dampak yang tidak dapat dinilai secara langsung adalah dampak psikologis. Dampak psikologis yang muncul paska bencana meliputi kejadian acute stress disorder (ASD). ASD merupakan respon kecemasan yang bial dibiarkan akan menimbulkan permasalahan psikologis lebih lanjut. Responden pada penelitian ini adalah semua korban yang selamat dari bencana lonngsor dan berusia dewasa. 
Berdasarkan hasil analisis didapatkan bahwa ketahanan seseorang terhadap kejadian ASD dipengaruhi oleh beberepa factor.

Factor karakteristik individu yang mempengaruhi terhadap ketahanan ASD meliputi umur dan penghasilan. Sedangkan karakteristik individu yang meliputi jenis kelamin serta pendidikan tidak memiliki korelasi terhadap ketahanan ASD.

Saran untuk puskesmas yang mempunyai daerah binaan rawan bencana sebaiknya mengadakan screening ASD pada penduduk guna mengantisipasi terjadinya ASD paska bencana. Meningkatkan kemampuan individu untuk siap menghadapi kejadian traumatik.

Saran untuk bidang keilmuan, hasil penelitian ini diharapkan mampu memberikan sumbangan referensi terkait kondisi paska bencana di seting komunitas.

Untuk peneliti selanjutnya Hasil penelitian dini dapat digunakan sebagai awal pengembangan penelitian dengan Hubungan Karakteristik Individu ...... tema yang sama yaitu mengenai bencana dan factor yang mempengaruhi kejadian ASD. Penelitian selanjutnya sebaiknya menggunakan metode wawancara mendalam untuk mengetahui karakteristik individu yang paling berpengaruh terhadap ketahanan ASD paska bencana.

\section{REFERENSI}

Alen \& John. (2005).World didasater report: Coping with Trauma Hope through Understanding 2nd ed. USA : American Psyciatric Publishing. Diakses melalui

https://www.ifrc.org/worlddisasters-report-2014/data

Badan Nasional Penanggulangan Bencana (BNPB). 2015. Data Informasi Bencana Indonesia. Diakses melaluihttp://dibi.bnpb.go.id/De sInventar/dashboard.jsp?country $\underline{\text { code }=\text { id }}$

Center For Disaser Phylanthropy (CDP) . 2014. The Impact of Disaster on Public Health. Diakses melalui http://disasterphylanthropy.org

Diehl, Coyle \& Vief, 1996. Age and Sex Differences in Strategy of Coping and Defence Across the Life Span. Psychology and Aging. No 1 127-139 vol 11. American Psychological Assosiation. Diakses melalui http://www.researchgate.net/ 
International disaster databased. (2014).

Disaster in Number 2013. Diakses melalui http://www.cred.be/

Langan, J.J \& James, D.C. (2005).Preparing Nurses For Disaster Management.New jersey:Pearson Prentice Hall

Notoatmodjo, S. 2003. Pendidikan dan Perilaku Kesehatan. Jakarta : Rineka Cipta

Oklahoma State Departement of Health. (2012). Access and Fuctional Needs Guidance resource Book and Country template The Whole Community Approach. Diakses melalui http://www.ok.gov/

Potter, Patricia Ann\& Perry Anne Griffin. (2009). Fundamental Of Nursing. Philadelpia: Mosby Elsevier

Pusat Penanggulangan Krisis Kesehatan Kementrian Kesehatan Republik Indonesia. (2015). Statistik kejadian bencana 2014. Zulkarnaian Gafar. Diakses melalui :www.penanggulangankrisis.dep kes.go.id/

Ranimpi, YY. 2009. Kemiskinan dan Kesehatan Mental di Nusa Tenggara Timur (Suatu Hampiran Teoritis). Jawa Tengah : UKSW

Strawbridge, W.J (2002). Education level andPhysical activity reduce the risk of subsequent depression for adult. American journal of epidemiology vol 156 no 4 p 328-334

Hubungan Karakteristik Individu . . . . . .
Stuart, Gail W. (2013). Principles and Practice of Psychiatric Nursing $10^{\text {th }}$ Ed. Canada. Mosby Elsevier

Undang-Undang No.24 tentang penanggulangan Bencana.2007. Diakses melalui http://www.litbang.depkes.go.id f 